\title{
MARRIAGE STRATEGIES AMONG IMMIGRANTS IN SPAIN
}

\section{ESTRATEGIAS MATRIMONIALES DE LOS INMIGRANTES EN ESPAÑA}

\author{
María SÁnchez-Domínguez msanchez@geps.es \\ Universidad Complutense de Madrid and Grupo de Estudios "Población y Sociedad". Spain.
}

HeLga de ValK Helga.De.Valk@vub.ac.be

Vrije Universiteit Brussels, Interface Demography. Belgium.

DAVID ReHER dreher@geps.es

Universidad Complutense de Madrid and Grupo de Estudios "Población y Sociedad". Spain.

\begin{abstract}
This paper studies patterns of endogamous marriages of immigrants in Spain by using data from the National Immigrant Survey of Spain (2007). First of all, we examine patterns of endogamous marriage and links between migration and marriage. Second, we assess the factors influencing the likelihood of being in an endogamous marriage. Our analyses focus on persons married either immediately before, during or after arrival in Spain originating from six countries: Morocco, Romania, Ecuador, Colombia, Argentina, and a group of other developing countries. Results show that the level of endogamy is highest among the Moroccan immigrants and lowest for those coming from Colombia. The likelihood of an endogamous union is higher for those married before migration compared to those married later. Furthermore, chances on endogamy are lower for more highly educated. Women are less likely than men to be in endogamous unions.
\end{abstract}

\section{KEYWORDS}

Endogamy, Immigrants, Marriage, Spain.

\section{RESUMEN}

En este trabajo se analizan los patrones endogámicos de la población inmigrante en España haciendo uso de la Encuesta Nacional de Inmigrantes (2007). En primer lugar, se examinan los patrones de matrimonio endogámico y los vínculos entre la migración y el matrimonio. En segundo lugar, se evalúan los factores que influyen en la probabilidad de estar en un matrimonio endogámico. El análisis se centra en las personas casadas inmediatamente antes, durante 0 después de la llegada a España procedentes de seis países: Marruecos, Rumania, Ecuador, Colombia, Argentina y un sexto grupo compuesto por inmigrantes oriundos de otros países en desarrollo. Los resultados muestran que el mayor nivel de endogamia se produce entre los inmigrantes marroquíes y el menor en el caso de los inmigrantes colombianos. La probabilidad de una unión endogámica es mayor para los casados antes de la migración en comparación con los que se casaron tras la llegada a España. Por otro lado, la endogamia matrimonial es menor en el caso de los inmigrantes cuyo nivel educativo es elevado. Por último, las mujeres son menos propensas que los hombres a estar en una unión endogámica.

\section{Palabras Clave}

Endogamia, España, Inmigrantes, Matrimonio. 


\section{INTRODUCTION $^{1}$}

Partner choice and mating practices have been the subject of studies in the field of migration and integration for a long time. Much of this work has concentrated on how marriage is related to integration into the host society. From the classic assimilation view, intermarriage is perceived as the end phase of assimilation: indicating full absorption into the new society (Gordon 1964). Most of these studies have been conducted in societies with long immigration histories like the United States (Alba and Golden 1986; Kalmijn 1993 1998; Pagnini and Morgan 1990), though recently this line of work has been expanded to Western European countries with different immigration experiences (Kalmijn and Van Tubergen 2006; Rodriguez 2006; González-Ferrer 2006; Cortina et al. 2008). This literature generally focuses on a limited number of immigrant groups, making it hard to generalize to other groups of immigrants.

Less attention has been paid specifically to ethnic endogamous marriage patterns. Just like intermarriage, ethnic in-marriage is also a product of definable strategies though these are much different than those leading to marriage outside of the native group. These strategies are normally related to group promotion and protection that, under certain circumstances, are perceived to be more valuable or more feasible than strategies oriented towards integration or assimilation. This type of behavior characterized migrants in historic societies where in-marriage was as or even more prevalent than intermarriage (Reher 2004). Disentangling the nature of these strategies and the way constraints condition choices is a central goal of this paper.

In this paper we go beyond the existing literature in different ways. First, we disentangle the link between migration and marriage decisions. The unique data set we use enables us to pinpoint the decision to marry with respect to the decision to migrate, thus affording a nuanced view of the links holding between marriage and migration. This will enable us to distinguish between endogamous marriage as a choice before and potentially related to migration itself, or as a strategy developed within the context of the host society and thus one that is constrained by the functioning of the local marriage market, which may vary markedly for different immigrant groups for either cultural or socio-demographic reasons. Relating marriage choices specifically to migration choices is infrequent in the literature. Most work on immigrant marriage choices has been based on register and census data (Cortina et al. 2008; Coleman 2008; Kalmijn 1998; Khoo 2004; Lee and Fernandez 1998; Qian 1997; Van Tubergen and Maas 2007). The limited retrospective information available for the couple in

\footnotetext{
${ }^{1}$ Preliminary versions of this paper have been presented at the Seminar "Multi-attribute analysis and projection of ethnic populations" organized as part of the European Science Foundation Network "Quantitative Methods in the Social Sciences" (QMSS), Jevnaker, Norway, 3-5 June 2009, and at the "Conference of National Survey of Immigrants" of the UNED at Madrid, Spain, 4-6 March 2010. Research for this paper has received generous funding from the Ministry of Education of Spain (SEJ2005 - 02395/SOCI) and the Ministry of Science and Technology of Spain (CSO2008-03616/SOCI).
} 
these rich and ubiquitous data sources often makes it difficult to get at more nuanced insights into the mechanisms that are behind the choices for endogamous or exogamous marriages. Second, this paper focuses on immigrants in Spain, where the importance of immigration is a relatively recent phenomenon. We will test whether the same processes and mechanisms related to endogamous marriage as found in studies of older immigrant countries also hold for Spain (for recent studies on Spain, see Cortina et al. 2008; Esteve et al. 2009). Third, marriage patterns for both men and women originating from a wide range of countries are assessed separately and in relatively great detail. Wherever possible the specific characteristics of both the ego and his/her marriage partner are included.

\section{AN EXPLANATORY FRAMEWORK}

Theories of intermarriage have pointed out the importance of opportunity structures and meeting chances (Kalmijn 1998). Opportunities to meet a potential Spanish partner are much larger for immigrants who migrated to Spain single. The chances of marriages contracted before migration are more likely to be with a partner from the same origin as the chances of meeting a Spanish partner are smaller for this group then they are for those who move single. Related to this point, we can interpret marriage decisions in origin to be basically constrained by local marriage markets independent of migration. As the time of departure nears, however, marriage choices could well be influenced by migration strategies. This could take place in many different ways. Initially it could be a strategy designed to make the migration move easier, either by guaranteeing it was done as a couple (a team) or, conversely, as a way of securing legal status more easily, in the case with intermarriage to a person of Spanish origin. Once in Spain, the direct marriage/migration link should weaken and the effects of local marriage markets should become predominant. Here, marrying in can be interpreted as a strategy of protection, self-defense and selfpromotion, as well as one in which the effects of more frequent contacts with persons of any given origin are of fundamental importance for meeting a potential partner. In any case, the degrees of separation between local origin-based social networks and Spanish-based ones are an essential part of the way marriage markets work.

Opportunities to meet a co-ethnic partner are thus related to the potential marriage market. It has been argued that the larger the size of the own ethnic group the higher the chances that contacts will be predominantly within the own ethnic group (Van Tubergen and Maas 2007). As a result the chances for intermarriage will decrease. The likelihood of endogamous marriages is related to both the intensity of arrivals of potential partners from any given origin and the number of these potential partners already in Spain. When arriving in the host society the composition of this marriage market may not be the same for migrant arriving in different periods.

A range of studies has shown that individual characteristics are relevant for partner choice and intermarriage. The level of education is among the most important factors influencing the chances of being in a mixed marriage. It is suggested that the more highly 
educated will tend to attach less importance to ethnic group boundaries and will be more open to mixed relationships. In addition, the chances for immigrants to meet potential native partners increase when attending higher education (Lieberson and Waters 1998). In different studies it was indeed shown that more highly educated are more likely to outmarry than are those with lower educational levels (González-Ferrer 2006; Kalmijn 1998; Qian and Lichter 2001).

Related to this, meeting chances with Spaniards are likely to increase when attending school in Spain. Interacting with Spaniards on a day to day basis makes it more likely to meet a potential spouse outside of the own group (Blau and Schwartz 1984). Being in Spain for study purposes already makes it therefore more likely to get in contact with Spaniards as one can expect that the majority of students will be of Spanish origin.

It has been suggested that linguistic and cultural differences between the sending and the host country may hamper intermarriage of immigrants. Social interaction is more difficult for those migrants who do not speak the language well, therewith potentially reducing the chances of ethnic intermarriages (Kalmijn and Van Tubergen 2006). Furthermore, religious differences may also potentially influence the likelihood of ethnic intermarriage. For the Netherlands, for example, it was shown that religious homogamy is still rather important among the Muslim population as well as among Christians. In fact, this is an extension of the cultural argument mentioned earlier. In Spain we have the unique opportunity to study marriage strategies for cultures and histories that are very different from Spain's and compare them to others where there is great affinity.

Migration decisions of men and women are found to be different in previous research. Men more often migrate independently and as singles even though the numbers of female migrants have risen as well. For women it often has been argued that they are more likely to be followers of migration and move for family related reasons more often than is the case for men (Castles and Miller 2004). In recent years these arguments have often been contested and gender difference in migration moves and decisions have been debated (Carling 2005; Donato et al. 2006). Some studies on intermarriage indicate that women, with the exception of Asian women, are more likely to be in endogamous relations (De Valk et al. 2004; Qian and Lichter 2001). Research from the Netherlands showed no differences in levels of intermarriage by gender for some groups (Kalmijn and Van Tubergen 2006) and the same was the case for a recent study in Germany (González-Ferrer 2006). Nevertheless, some have pointed to the role of religion in the level of interethnic mixed marriages for women. Muslim women are reported to be less likely to outmarry due to the fact that when a Muslim woman marries a non-Muslim the children are lost for Islam (Hooghiemstra 2003). All in all, based on these previous studies we expect that women should be more likely to be in an ethnic endogamous marriage than men. A country like Spain, where many immigrants come from countries that are culturally akin to the host society, should provide an interesting test case for this hypothesis.

At the same time factors influencing marriage choices as well as the linkage between marriage and migration may be different for men and women. This is true when they are affected by the existing numbers of potential partners. For these reasons, we 
should not expect the marriage chances or their determinants to be similar among men or women. These disparities could affect overall levels of endogamy, age differences in age at marriage, as well as human capital accumulation. Human capital for example may be much more important for men, as a crucial asset for mating, while for women it may be less the case. So we expect to find interaction effects between gender and the different determinants of endogamy.

Based on these insights from previous studies we expect that levels of ethnic endogamous marriages will be higher among groups whose presence in Spain is relatively recent (Portes and Zhou 1993; Portes and Rumbaut 2001; Kalmijn and Van Tubergen 2006; Portes 2008) as well as those where the ethnic community is larger, for those having arrived at an older age, for those with lower levels of education (Merton 1941; Lieberson and Waters 1998; Kalmijn 1993, 1998; Qian and Lichter 2001; GonzalezFerrer 2006), for those haven't studied in Spain (Blau and Schwartz 1984) or those who haven't acquired Spanish citizenship. The cultural affinity with Spain as well as the historical depth of traditional contacts between the societies of origin and destination will also be important factors contributing to marriage decisions. Related to this, the ability of the culture (Kalmijn and Van Tubergen 2006) and society in origin to constrain choice in the host society is also important, as is the strength of the transnational ties of different ethnic groups. Finally, levels of in-marriage will vary by sex as men and women potentially have different migration strategies which affect their chances of endogamy in dissimilar ways.

\section{BACKGROUND ON RECENT IMMIGRATION TRENDS TO SPAIN}

Until fairly recently, Spain was a country with a long history of emigration and little experience as a destination for international migrants (Sánchez Alonso 2001; Arango 2004). Only a decade ago, towards the end of the 1990s, the million or so non-natives living in Spain made up a small fraction of the total population (3\%). Ten years later, in 2009 , the non-native population of the country had grown to nearly 6.5 million persons, about $13.8 \%$ of the entire population. One major result of this is that the total population Spain, near stagnation a decade ago, has grown to well over 46 million inhabitants, with immigrants contributing to over three quarters of that growth. The contribution of immigrants to birth rates and especially to the number of births in the country has been enormous, both because of the continued arrival of new immigrants and to the fact that that immigrant mothers tend to have fertility levels that are substantially higher than native mothers. In $1998,4 \%$ of all births were to foreign mothers, while a decade later this percentage had increased to $19 \%$. Had it not been for recent immigration, by now natural growth rates in Spain would be negative and would remain that way for decades to come (Roig and Castro 2007). For the first time in Spanish history, immigration has become a structural phenomenon of Spanish society. The massive influx of immigrants has strongly affected the make-up of its active population and population age structures. Immigration is now an important political, economic and social issue. 
An important characteristic of immigration to Spain is that immigrants originate from a relatively small set of countries (Reher et al. 2008, Reher and Requena 2009). The three most important groups make up nearly one third of the total number of immigrants in the country, and nearly $60 \%$ of immigrants come from only 10 different countries of origin. According to the most recent estimates available (1st January 2009), the five different origins used in this paper (Moroccans, Romanians, Ecuadorians, Colombians and Argentineans) make up approximately one half of all non-natives in Spain born in developing countries. A decade ago Moroccans were the most important immigrant group in the country ${ }^{2}$. Since then, the make-up of the immigrant population has changed substantially, with immigrants from South America and from Eastern Europe emerging as important components of the total immigrant population.

This extremely rapid growth of immigration in Spain was determined by three main factors (Requena and Reher 2009). For one, from the mid-1990s Spain underwent a prolonged period of economic growth, among the highest in Europe, which was accompanied by profound social change. Jobs opened up in the booming construction sector, in rural areas of the country and in personal services. This pattern of job growth, frequently in occupations shunned by Spaniards, was also stimulated by very important changes in the age structure of the Spanish population which was entering into a prolonged period of relative scarcity in the supply of labor related to the drastic reduction in fertility starting in the late 1970s. The final reason for the migration boom -and especially for specific timing of the trend change in 2000-2001 - can be found in liberal immigration policies existing in the country. In the Ley de Extranjería (2000) immigrants were offered full social services (health and education) if they were on the on-going population register, regardless of their legal status. Despite a progressive tightening of this policy, especially after 2003, often at the behest of the European Union (restrictive visas, etc), in Spain migration policy continues to be much more liberal than in many other countries of the European Union.

\section{DATA AND METHODS}

\section{Data and basic analytical approaches}

The data used in this study come from the National Immigrant Survey of Spain conducted between November 2006 and February 2007 (hereafter, NIS 2007). The total sample consists of 15,465 respondents living in Spain at the time of the interview but who are foreign born, at least 16 years old, and who had resided in Spain for at least a year or had the intention of doing so. The NIS 2007 contains ample data regarding partnering and co-residential strategies of immigrants which can then be assessed in

\footnotetext{
${ }^{2}$ This estimate is based on immigrants from the developing world.
} 
terms of specific socio-demographic characteristics and concrete migration history of those interviewed ${ }^{3}$.

In this paper, we apply an analytical strategy based on a bivariate and multivariate analysis of the likelihood of being in an ethnic endogamous union. For this analysis, only married couples currently residing together where the respondent arrived in Spain after 15 years of age and whose marriage took place between one year prior to arrival in Spain and 2007 will be used $(N=1,847)$. Finally a closer look will be taken at the main characteristics of these ethnic endogamous unions, making specific use of the migratory situation at marriage of both partners $(N=1,210)$.

Throughout this study, the immigrant population by origin will be divided into the following groups: Morocco, Romania, Ecuador, Colombia, Argentina and a group containing the rest of immigrants from developing countries of origin. Together the five separately defined countries cover about 50 per cent of the immigrants from developing nations in Spain. Each of them has very different migration histories and historical links with Spain. Morocco has long-standing links with Spain though cultural differences are very great. Argentina has a similar culture and has always had strong traditional links to Spain. Colombia has only moderate historical links to Spain via migration, but its cultural affinity is unquestionable. Ecuador, on the other hand, has almost no traditional links to Spain and is a country of very recent migration, yet it shares important cultural roots with Spanish society. Finally, Romania has no cultural links to Spain and no shared migration history.

\section{Modeling for endogamous marriages}

A large part of this paper is centered on the study of endogamous marriage in comparison with exogamous marriages (with Spaniards or persons of other origins). By definition, the endogamous marriages are those in which the respondent and the partner share the same country of birth. The selection criteria and variable definition for part of the analysis have implications which deserve brief mention. Only marriage strategies of first generation of immigrants will be analyzed. By implication, there may be a potential underestimation of endogamous marriages within the same ethnic group because second generation immigrants ${ }^{4}$ are included as Spaniards. Secondly, since this analysis is based exclusively on marriage, consensual unions have been excluded. Marriage continues to be the main source of partner formation among immigrants, though the incidence of cohabitation may be on the rise (Cortina et al. 2008). Considering unions among immigrants currently living in Spain, slightly over half are currently married whereas a sixth of the immigrants cohabit with their partner (of whom mainly Latin Americans). Endogamous unions are far more prevalent than exogamous but an important part of endogamous unions are comprised of situations in which spouses currently do not co-reside. This latter group may end up

\footnotetext{
${ }^{3}$ For a more complete description of the contents of the NIS, see Reher and Requena (2009).

${ }^{4}$ Second generation immigrants are those who were born in Spain but with one or two foreign born parents.
} 
making use of family reunification policies to bring their spouses to Spain. This situation is normally more frequent among Moroccans. Finally, and as a consequence of the last point, only currently co-resident married couples are used in this analysis, and couples living apart have been excluded. In this way we limit the potentially distorting effects of potentially dysfunctional marriages or ones in the process of family regrouping.

\section{Independent variables}

Within the models presented here, eight different explanatory variables referring to the respondent have been used: sex, country of origin, age at arrival to Spain, year of arrival, time to marriage, educational level, studies in Spain, and Spanish citizenship.

Country of origin is based on country of birth of the person and includes persons from five countries of origin: Morocco ( $n=290)$, Romania ( $n=195)$, Argentina ( $n=124)$, Ecuador $(n=161)$, and Colombia $(n=212)$. Those born in other developing countries and not distinguished separately are included in a sixth category (other developing countries) $(n=865)$.

The age at arrival to Spain is based on the exact age (in years) at entry. This information is recoded into four groups referring to different timing of the migration experience in the life course 16-20, 21-25, 26-30, and older than 30.

Year of arrival in Spain of the respondent has been coded into two periods (arrival before 2000 and 2000-2007) so as to distinguish different migration phases, one of very gradual migration flows and the other with extremely intense migration.

The variable time to marriage situates the timing of marriage with respect to the timing of migration. Respondents who married around the time of migration (both events in the same year) are used as the reference category. These respondents are compared with respondents who married one year before migration, those marrying soon after migrating (one year after) and finally those marrying two or more years after migration. The reference category indicates strategies for marriage and migration may be linked. In the second category, marriage strategies are, at least for the most part, independent of migratory decisions. The last two categories reflect the effect of the duration of the stay in the host country and how local marriage markets work. Marriage at this stage is unlikely to be linked to the decision to migrate but is clearly influenced by the duration of stay in the host society and thus is related to strategies of assimilation, of group identity or of local marriage markets unrelated to longer-range migration strategies.

Educational attainment has been grouped into three educational levels: those with primary education or less (reference category), those who finished secondary education and those who finished higher post secondary education.

Studies in Spain is a dummy variable that has been included to indicate whether the person ever studied in Spain (the reference category are those who did not study in Spain). Spanish citizenship reflects the citizenship status of the respondent at the time of marriage. Persons with Spanish citizenship since birth were eliminated so as to cut down on the possibility of classifying true Spaniards as immigrants.

For summary statistics of these independent variables, see table 1. Given the dichot- 


\section{Table 1.}

Sample characteristics and distribution of independent

variables by immigrant group (\%)*

\begin{tabular}{|c|c|c|c|c|c|c|}
\hline & Morocco & Romania & Argentina & Ecuador & Colombia & $\begin{array}{c}\text { Other } \\
\text { developing } \\
\text { countries }\end{array}$ \\
\hline $\mathrm{n}$ & 290 & 195 & 124 & 161 & 212 & 865 \\
\hline Female & 36.2 & 56.9 & 58.1 & 59.6 & 74.5 & 56.0 \\
\hline \multicolumn{7}{|l|}{ Age arrival } \\
\hline $16-20$ (ref) & 19.7 & 22.1 & 4.8 & 16.8 & 9.9 & 19.0 \\
\hline $21-25$ & 37.6 & 50.3 & 29.8 & 42.9 & 33.0 & 31.4 \\
\hline $26-30$ & 29.3 & 20.5 & 35.5 & 18.6 & 24.1 & 27.4 \\
\hline$>30$ & 13.4 & 7.2 & 29.8 & 21.7 & 33.0 & 22.2 \\
\hline \multicolumn{7}{|l|}{ Year arrival } \\
\hline Before 2000 (ref) & 70.7 & 8.2 & 34.7 & 23.6 & 33.0 & 52.5 \\
\hline After 2000 & 29.3 & 91.8 & 65.3 & 76.4 & 67.0 & 47.5 \\
\hline \multicolumn{7}{|l|}{ Time to Marriage } \\
\hline 1 year before & 19.7 & 19.0 & 15.3 & 16.1 & 8.0 & 12.9 \\
\hline year of arrival (ref) & 2.1 & 5.6 & 5.6 & 0.0 & 3.3 & 7.2 \\
\hline 1 year after & 10.0 & 15.4 & 25.8 & 10.6 & 16.0 & 14.9 \\
\hline+2 years after & 68.3 & 60.0 & 53.2 & 73.3 & 72.6 & 65.0 \\
\hline \multicolumn{7}{|l|}{ Education } \\
\hline Primary (ref) & 35.9 & 7.2 & 8.1 & 19.3 & 13.2 & 12.1 \\
\hline Secondary & 51.4 & 82.6 & 47.6 & 68.3 & 66.0 & 56.2 \\
\hline Higher & 12.8 & 10.3 & 44.4 & 12.4 & 20.8 & 31.7 \\
\hline Studied in Spain & 6.6 & 3.1 & 12.9 & 1.9 & 9.4 & 14.1 \\
\hline Spanish citizenship & 1.7 & 0.5 & 15.3 & 0.6 & 4.7 & 13.5 \\
\hline
\end{tabular}

Source: NIS 2007, unweighted data.

*Percentages refer to married couples whose marriage took place between one year prior to arrival in Spain and 2007. 
omous independent variables (endogamous marriage or not) for this paper we have used a series of logistic regression models ${ }^{5}$.

\section{RESULTS}

\section{Basic patterns of marriage and migration}

In this paper we explicitly aim to link migration decisions to marriages strategies used by men and women. In order to get insights into the timing of migration and marriage, figure 1 gives the percentage of all married respondents who married their current spouses (max one year) before, around or after migration for each of the countries of origin 6 .

From these data, men appear to be less likely than women to marry around the time of migration, indicating that marriage and migration are less connected for them. Overall, both sexes marry after migration (around 80\%), indicating that they moved to Spain either as singles or at least were not married to their current spouses. The weight of marriages well after migration ( $>1$ year), however, is considerably higher among men than among women. There is substantial variation between the timing of marriage related to migration among ethnic groups. Women coming from Colombia are the least likely to be married before migration whereas among women from Morocco are the most likely to have married just prior to migration. Marriage and migration appear to be more clearly linked among Moroccans than they are among other groups, with more than 80 per cent of Moroccan men marrying after arrival and important percentages of Moroccan women (44\%) marrying just before or at the time of arrival. This suggests the existence of a very specific type of endogamy among Moroccans that will be explored further later in this paper.

Table 2 shows the share of endogamous unions among all current co-resident marriages by gender divided by individual characteristics. Among men, endogamy is highest among Romanians, Moroccans and especially Ecuadorians, and lowest among Argentineans. Among women, the levels are close to $80 \%$ for Moroccan women which are nearly 2.5 times higher than among Colombians. The differential ability of ethnic marriage markets to constrain choice is quite visible in these results. This ability is related to the time an ethnic community has been in the country, to its size, the educational levels of its members and of course to the cultural and historical ties linking it to Spain.

\footnotetext{
${ }^{5}$ Unweighted data have been used for all models.

${ }^{6}$ It is important to remember that marriages taking place more than 1 year prior to migration in Spain are not included in these data.
} 
Figure 1.

Distribution of immigrants in Spain by timing of marriage

with respect to the timing of migration (\%)*

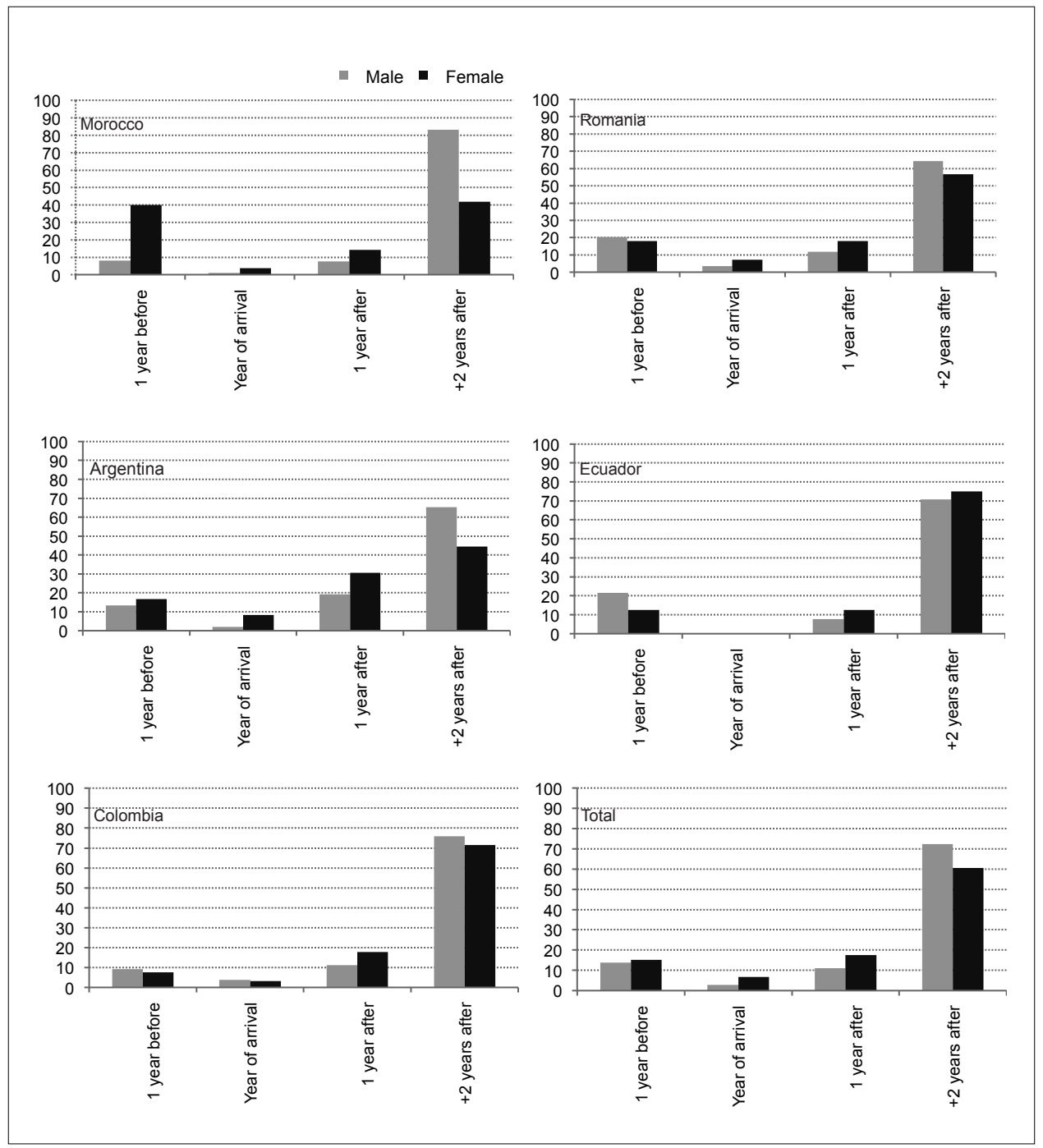

Source: NIS 2007, unweighted data.

*Percentages refer to married couples whose marriage took place between one year prior to arrival in Spain and 2007. 
Table 2.

Percentage of endogamous marriage among immigrants in Spain by main characteristics

\begin{tabular}{lccc}
\hline & Male & Female & Total \\
\hline Country of origin & & & \\
\hline Morocco & 77.8 & 78.1 & 77.9 \\
Romania & 83.3 & 67.6 & 74.4 \\
Argentina & 40.4 & 50.0 & 46.0 \\
Ecuador & 86.2 & 49.0 & 64.0 \\
Colombia & 53.7 & 27.2 & 34.0 \\
Other developing countries & 45.1 & 27.9 & 35.5 \\
Total & 59.9 & 40.7 & 49.3 \\
\hline Year at arrival to Spain & & & \\
\hline$<2000$ & 51.0 & 26.4 & 39.6 \\
$>$ 2000 & 70.4 & 49.3 & 57.1 \\
Total & 59.9 & 40.7 & 49.3 \\
\hline Age at arrival to Spain & & & 51.6 \\
\hline$<25$ & 56.8 & 47.7 & 46.7 \\
$>25$ & 63.1 & 32.6 & 49.3 \\
Total & 59.9 & 40.7 & \\
\hline Education & & & 64.4 \\
\hline Primary & 80.0 & 51.0 & 33.3 \\
Secundary & 65.3 & 41.0 & 49.3 \\
University & 32.7 & 33.9 & \\
Total & 59.9 & & \\
\hline
\end{tabular}

Source: NIS 2007, unweighted data.

*Percentages refer to married couples whose marriage took place between one year prior to arrival in Spain and 2007.

Generally, endogamous unions are much more prevalent among men than they are among women and are also much more prevalent among those immigrants arriving after the beginning of the migratory boom in the year 2000 . This result confirms our expectation that when migration flows are fairly weak and the size of ethnic groups resident in the host country is small, endogamy tends to be low. They increase substantially as the pace of migration accelerates. It is interesting to observe that endogamous marriages 
Figure 2.

Percentage of endogamous marriages by sex and time to marriage*

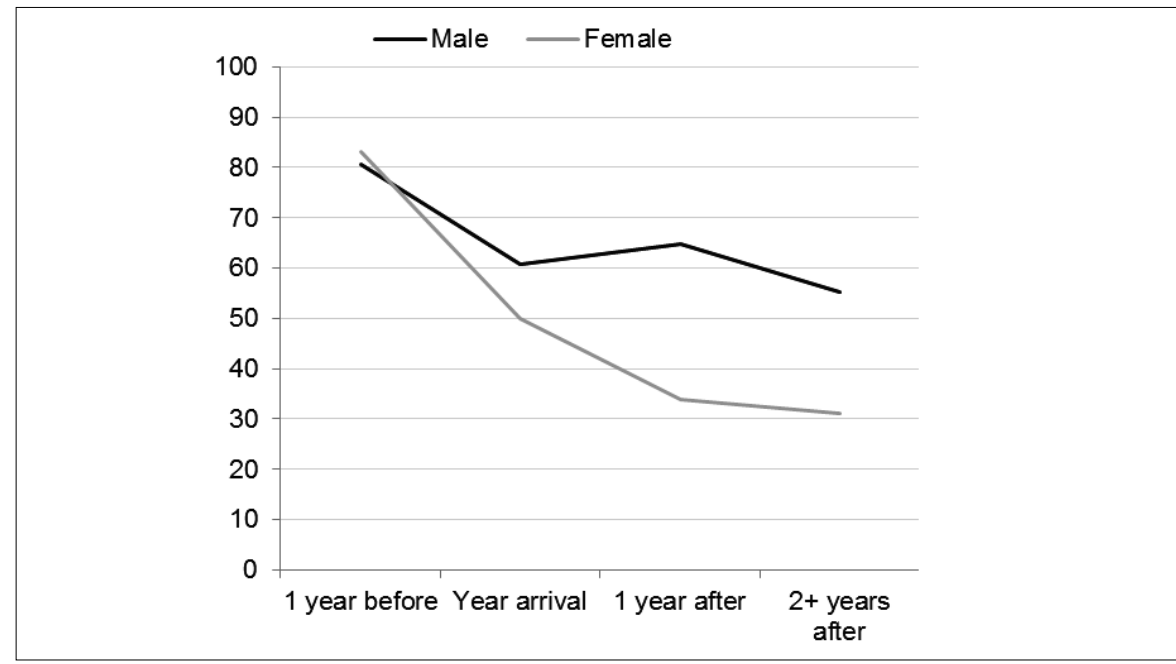

Source: NIS 2007, unweighted data.

*Percentages refer to all married couples whose marriage took place between one year prior to arrival in Spain and 2007.

are more important for men arriving in Spain at an older age and for women arriving at a younger age, thus suggesting that the endogamous marriage market works differently on this point for men and women. Finally, endogamous unions tend to be higher among men and women with lower educational levels, though here the differences among men are far more conspicuous than they are among women. This result also gives strong confirmation to the hypothesis that people with higher education have easier access to non-ethnic marriage markets.

Levels of endogamy are compared by the timing of marriage and migration for men and for women in figure 2. These results give strong support to our expectation that endogamy will decline in importance as the length of people's stay in Spain increases. It is also apparent that before migration there is practically no difference between men and women in the importance of marrying-in. This situation changes after arrival in Spain, as the differences by sex increase dramatically. For marriages taking place two or more years after arrival, levels of endogamy among men are much higher than they are among women. These results are in contradiction with a part of the existing literature that suggests that endogamy among women should be more important than it is among men (De Valk et al. 2004; Hooghiemstra 2203; Qian and Lichter 2001). 


\section{Determinants of marriage behavior}

In order to test relevant hypotheses logistic regression models on the chances of being married endogamous were specified. In the model based on the full sample (table 3) most of the results are significant, confirming many of the initial hypothes ${ }^{7}$. There are clear gender differences in the likelihood of entering into an endogamous union, with women much less likely to be in these marriages than men. The significant odds ratio suggests that endogamous marriages are about two thirds more likely among men than among women.

There are strong and significant differences in endogamous marriages among different ethnic groups. Migrants from Morocco are by far those most likely to be in endogamous unions, followed at some distance by Romanians (differences are not statistically significant). Among the South American groups, marital endogamy is much lower, with the likelihood of in-marrying 50\% lower than the reference group among Ecuadorians, $70 \%$ lower among Argentineans and more than $80 \%$ lower among Colombians. These results offer strong confirmation of our hypotheses on differences in endogamy by migrant origin.

Migrants who arrive at peak working ages (21-30) are the ones most likely to be in endogamous unions, while the prevalence of these unions are lower among those arriving at younger (before 21) or relatively older (after 30 ) ages, though the results are not statistically significant at standard levels. The pattern for the moment of arrival in Spain is quite clear and gives strong support to the original hypotheses regarding period effects. Those arriving during the period of strongest migration flows (after 2000) are much more likely to be in endogamous unions than those who arrived when migration to Spain was only modest. These results suggest that marriage markets tend to work differently in times of intense migration, a result probably related to the fact that size of the local ethnic marriage market grows significantly in times of intense migration. For those persons arriving before 2000 , the relative permeability of Spanish society for immigrants was far greater than during the later period.

As expected, those who marry before migration are much more likely to be married endogamous than is the case for those who marry at the moment of migration or afterwards. The effect observed around the time of migration is an example of how marriage options may be an integral part of migration strategies, while the effect after arrival indicates that the marriage market is expanded significantly to the host country.

The expected effect of education is fully corroborated by the findings: the higher educated a person is the less likely he/she is married endogamous in comparison with a person with a primary education. Education gives people greater access to marriage markets that include persons of different origins. In addition, those who studied in Spain are significantly less likely to be married to a partner from the same country of origin.

\footnotetext{
${ }^{7}$ These models were also run for a subsample of migrants coming to Spain as singles. The second set of models showed overall similar findings to those presented here. This suggests that the presented results are robust.
} 


\section{Table 3.}

Determinants of endogamous marriages among immigrants in Spain (odds ratios)*

\begin{tabular}{|c|c|c|}
\hline & \multicolumn{2}{|c|}{ Full Sample } \\
\hline & $\operatorname{Exp}(\beta)$ & S.E. \\
\hline Sex (ref=male) & $0.386^{\star * *}$ & 0.116 \\
\hline \multicolumn{3}{|l|}{ Countries } \\
\hline \multicolumn{3}{|l|}{ Morocco (ref) } \\
\hline Romania & 0.703 & 0.251 \\
\hline Argentina & $0.314^{* * *}$ & 0.265 \\
\hline Ecuador & $0.516^{\star *}$ & 0.246 \\
\hline Colombia & $0.198^{\star * *}$ & 0.230 \\
\hline other developing & $0.193^{\star * *}$ & 0.178 \\
\hline \multicolumn{3}{|l|}{ Age arrival } \\
\hline \multicolumn{3}{|l|}{$16-20$ (ref) } \\
\hline $21-25$ & 1.337 & 0.166 \\
\hline $26-30$ & 1.180 & 0.179 \\
\hline$>30$ & 0.764 & 0.192 \\
\hline Year arrival (ref=before 2000) & $1.848^{\star * *}$ & 0.132 \\
\hline \multicolumn{3}{|l|}{ Time to marriage } \\
\hline 1 year before migration & $2.885^{\star * *}$ & 0.286 \\
\hline \multicolumn{3}{|l|}{ year arrival (ref) } \\
\hline 1 year after & 0.592 & 0.269 \\
\hline $2+$ years after & $0.510^{\star *}$ & 0.250 \\
\hline \multicolumn{3}{|l|}{ Education } \\
\hline \multicolumn{3}{|l|}{ Primary (ref) } \\
\hline Secondary & $0.636^{\star *}$ & 0.161 \\
\hline Higher & $0.388^{\star * *}$ & 0.190 \\
\hline Studies in Spain (ref=no) & $0.462^{\star \star *}$ & 0.212 \\
\hline Spanish citizenship (ref=no) & $0.595^{*}$ & 0.233 \\
\hline Nagelkerke Pseudo R2 & 0.35 & \\
\hline
\end{tabular}

Source: NIS 2007, unweighted data.

Note: ${ }^{*} p<0,05 ;{ }^{* *} p<0,01 ;{ }^{* * *} p<0,001$.

*Sample refers to married couples whose marriage took place between one year prior to arrival in Spain and 2007. 
Finally, having Spanish citizenship decreases the chances of being in endogamous unions, though here the effect is only significant at a low level ${ }^{8}$.

Both bivariate and multivariate analysis has shown that the likelihood of an endogamous union is much higher in the case of men than it is for women $60 \%$ in endogamous unions for men as opposed to $41 \%$ for women). In order to ascertain the extent to which the constraints on behavior are different for each sex, logistic regression models were specified for men and women separately (table 4). Men coming from Morocco, Romania and Ecuador are much more likely to be in endogamous unions than men from other origins, especially Argentina where the likelihood of marrying-in is $85 \%$ lower than in the reference category (Moroccans). A different pattern is found among women. Here again Moroccans show by far the greatest likelihood of being in an endogamous union with other ethnic origins far less likely to be in these sorts of union. The odds ratios in comparison to the reference category show a reduction in the likelihood ranging between two-thirds (Romanians) and almost nine-tenths (Colombians). Among women, all countries of origin differ significantly from the Moroccan group (reference category), with the exception of Romania, while for men this is only the case for Argentina and Colombia.

Regarding the effects of age at arrival on endogamous marriage we find opposite effects for men and women. Endogamous unions for men arriving young were lowest, increasing substantially for those arriving later. For women, on the other hand, the highest levels of endogamous unions can be found among women arriving rather young and the lowest levels holding for those arriving in higher age groups. The results for men conform to expectations while those for women are quite the opposite and suggest that for them the marriage market works in substantially different ways than for men. The effect of the period of immigration is similar for both sexes. In line with our hypothesis, those who married before the period of intense migration were far less likely to be in an endogamous relationship than those who married during the migration boom in Spain. Chances of endogamous marriages are much lower for those married after migration. Here, once again, the importance of the effect differs sharply by sex: coefficients are strongly significant for women and hardly significant at all for men (except for those married more than 2 years after migration).

Education shows very interesting differences in these models. For men, the results are highly significant and conform to expectations with more highly educated men much less likely to be in endogamous unions than men with low educational levels. With women, on the other hand, there does not appear to be any significant effect at all between education and marriage type. Basically this means that when implementing marriage strategies education for men really matters, but for women it does not. Our findings suggest that

\footnotetext{
${ }^{8}$ Initially our sample included persons with Spanish citizenship from birth and the results for this variable were strong and significant. This subgroup was removed from the sample so as to eliminate the likelihood that our estimates would be biased by including persons who had Spanish parents and thus participated in the host marriage market differently from other immigrants.
} 
Table 4.

Determinants of endogamous marriages among immigrants in Spain by sex (odds ratios) $^{*}$

\begin{tabular}{|c|c|c|c|c|}
\hline & \multicolumn{2}{|c|}{ Men } & \multicolumn{2}{|c|}{ Women } \\
\hline & $\operatorname{Exp}(\beta)$ & S.E. & $\operatorname{Exp}(\beta)$ & S.E. \\
\hline \multicolumn{5}{|l|}{ Countries } \\
\hline \multicolumn{5}{|l|}{ Morocco (ref) } \\
\hline Romania & 0.947 & 0.391 & 0.494 & 0.362 \\
\hline Argentina & $0.152^{\star * \star}$ & 0.388 & $0.382^{*}$ & 0.388 \\
\hline Ecuador & 1.036 & 0.430 & $0.322^{* * *}$ & 0.357 \\
\hline Colombia & $0.315^{\star *}$ & 0.382 & $0.146^{\star \star *}$ & 0.336 \\
\hline other developing countries & 0.244 & 0.238 & $0.136^{\star \star *}$ & 0.293 \\
\hline \multicolumn{5}{|l|}{ Age arrival } \\
\hline \multicolumn{5}{|l|}{$16-20$ (ref) } \\
\hline $21-25$ & $1.986^{\star *}$ & 0.275 & 1.055 & 0.215 \\
\hline $26-30$ & $2.299^{* *}$ & 0.291 & 0.782 & 0.239 \\
\hline$>30$ & $2.756^{* *}$ & 0.321 & $0.335^{\star * *}$ & 0.263 \\
\hline Year arrival (ref=before 2000) & $1.640^{\star *}$ & 0.203 & $2.033^{\star * *}$ & 0.185 \\
\hline \multicolumn{5}{|l|}{ Timing of Marriage } \\
\hline $\begin{array}{l}1 \text { year before migration } \\
\text { year arrival }\end{array}$ & 2.341 & 0.529 & $3.935^{\star \star *}$ & 0.352 \\
\hline 1 year after & 1.296 & 0.524 & $0.482^{*}$ & 0.321 \\
\hline $2+$ years after & 0.963 & 0.488 & $0.472^{*}$ & 0.295 \\
\hline \multicolumn{5}{|l|}{ Education } \\
\hline \multicolumn{5}{|l|}{ Primary (ref) } \\
\hline Secondary & $0.487^{\star *}$ & 0.263 & 0.682 & 0.223 \\
\hline Higher & $0.171^{\star \star \star}$ & 0.304 & 0.644 & 0.264 \\
\hline Studies in Spain $(r e f=n o)$ & $0.356^{\star * *}$ & 0.319 & 0.653 & 0.283 \\
\hline Spanish citizenship (ref=no) & $0.443^{*}$ & 0.336 & 0.801 & 0.332 \\
\hline Nagelkerke Pseudo R2 & 0.36 & & 0.36 & \\
\hline
\end{tabular}

Source: NIS 2007, unweighted data.

Note: ${ }^{*} p<0,05 ;{ }^{* *} p<0,01 ;{ }^{* * *} p<0,001$.

*Sample refers to married couples whose marriage took place between one year prior to arrival in Spain and 2007. 
a man's own human capital accumulation is a key asset he brings to the marriage market, while for women this seems not to be the case. In line with this result, having finished studies in Spain or having acquired Spanish citizenship lead to significantly lower levels of endogamy among men, but not for women, at least at standard levels of significance.

\section{DEEPENING OUR UNDERSTANDING OF ENDOGAMY}

Up until this point, endogamous marriages have been compared to exogamous current marriages. In this section we will address the issue of the heterogeneity of different types of endogamy. This analysis will enable us to asses, at least approximately, the existence of different types of strategy leading to ethnic endogamous unions.

The National Immigrant Survey has data on the origin, the year of marriage and the time of arrival in Spain for both the respondent and for his or her spouse as long as both reside in the same household. These data enable us to situate couples jointly with respect to the moment of marriage (for the couple) and the timing of migration for each of them. A simplified classification of marriages yields to the following classification: (1) both married in origin, (2) both the ego and the spouse just arrived, (3) the ego in origin and the spouse either in Spain or just arrived, (4) the ego in Spain and the spouse in origin or just arrived, (5) both married in Spain, and (6) others ${ }^{9}$. Including these typologies detecting different strategies is relatively straightforward (table 5).

\footnotetext{
${ }^{9}$ In this classification, 'in origin' refers to situations one year prior to the migratory move, 'same year as arrival' refers to situations in which marriage and migration take place in the same year and finally 'in Spain' refers to situations in which marriage takes place at least one year after arrival. There are nine possible combinations, so the five included in the table are the result of grouping. The biggest difficulty affecting this classification is related to the fact that data only exist for the year of marriage and of migration, thus limiting our ability to pinpoint exactly where the ego or the spouse was at the precise moment of the marriage. With crossover marriages (one spouse in Spain and one in origin), our classification scheme groups possible situations in the following way: one spouse in Spain (marriage takes place 1 year or more after arriving) and the other spouse either in origin (one year before migration) or either just before or just after the migratory move to Spain (same year). The category 'Others' includes: 1) when ego is in origin and the spouse just arrived to Spain; and 2) when ego is just arrived and spouse is in origin. These two situations have been classified separately from the others because it is impossible to know exactly whether or not the ego or the spouse was actually in Spain at the time of marriage.
} 


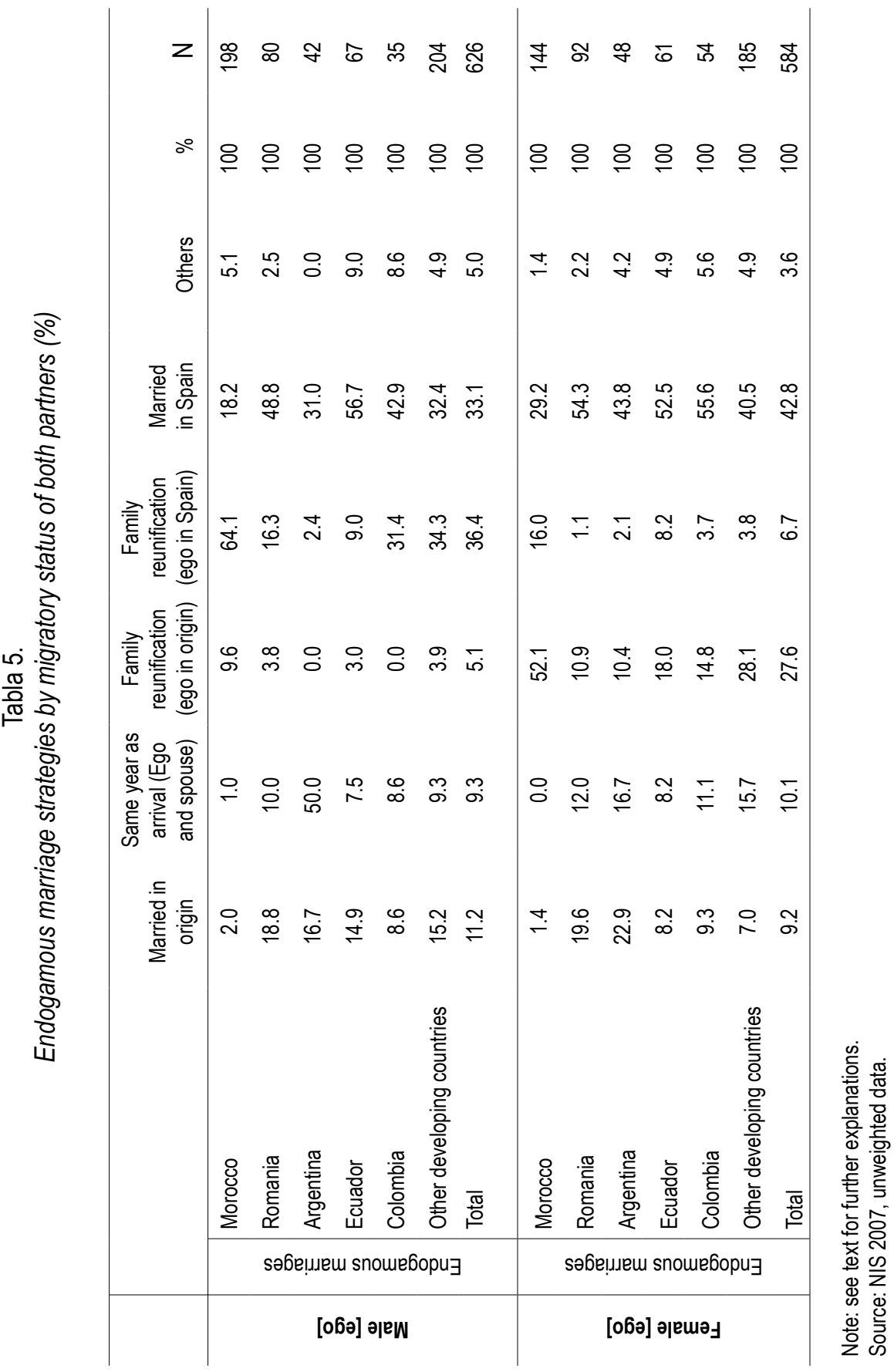

RIS monographic No.1. Immigration in Spain: InNOVAtive Perspectives, 139-166, 2011. ISSN: 0034-9712 
The results shown in this table can be summarized in the following points. Firstly, only about one tenth of endogamous marriages take place when both spouses are still in their country of origin ${ }^{10}$. There are, however, very important differences by ethnic origin, as among male egos, the importance of these unions are about nine times greater among Romanians than among Moroccans. For female egos, again Moroccans do not use this sort of strategy at all, as opposed to Argentinean women where almost one quarter of the marriages was conducted when both partners were still in Argentina. Differences are similar when looking at marriages taking place around the time of migration. Marriages taking place one year before or in the same year as migration may all be linked, directly or indirectly, to a migration strategy whereby the couple undertakes the migratory move together. In this sense the $68 \%$ of male egos or the $39 \%$ of female egos from Argentina show a starkly contrasting migratory strategy to that used by both men and women from Morocco (around 2\%). Part — but not all— of these differences could probably be attributed to the different age structures of these groups in Spain.

Secondly, the crossover marriages, where one spouse is in Spain and the other in the country of origin, are equally interesting. Here we are looking at a strategy in which one person establishes a foothold in Spain and then brings his or her spouse to Spain, likely making use of the status of the person already in Spain. All of the immigrant groups make use of this strategy, but with important differences. For Moroccans, this is the most important strategy underlying in-marriage patterns. Nearly two thirds of male egos are in Spain when they marry spouses who continue to live in Morocco. With female egos, it is the same pattern, but in the other direction: over half of all endogamous marriages involve a female ego in Morocco with her husband already in Spain, followed by a subsequent migration to Spain. At the other extreme, only $2 \%$ of male egos and $10 \%$ of female egos from Argentina do the same.

Thirdly, among all origins, family reunification is much more predominant when the male ego is already in Spain than when the female ego is. Men are the ones who bring their brides to Spain, not the other way around.

Finally, the importance of endogamous marriages with both spouses already in the host country is far less important among the Moroccans than it is among the other groups where often as many as $40-50 \%$ of the endogamous marriages are of this nature.

Of the three basic marriage strategies shown here, two of them are related to migration strategies. One of them is linked to the concept of undertaking the migration move together with your spouse. Another is a much more clearly defined strategy whereby the marriage to a person of the same origin facilitates the move to the host country. Only the last of these typologies is influenced strictly by the marriage market in the host society. These different strategies appear to have different socio-demographic trappings as well.

\footnotetext{
${ }^{10}$ Here, only marriages taking place one year before migration to Spain are included. Had marriages further removed from the moment of migration been used, these percentages would have been substantially higher.
} 
Age differences between spouses are much greater in crossover endogamous marriages (7 years) than in other types of endogamous unions (3 years) (not in Table). Related to this, the incidence of an older male spouse is far higher in these marriages than in the other types of union (about $75 \%$ as opposed to about $50 \%$ ). Data on education only exist for egos in the NIS, but for them crossover marriages are much more prevalent among persons of lower educational attainment than other types of endogamous marriages, with the opposite effect holding for those of higher educational attainment. Nearly two thirds of crossover marriages involve men arriving in Spain before the year 2000, with a similar proportion affecting women who arrived after that date (not in table).

While these descriptive data show clear patterns, they suggest that further research on the characteristics of endogamous unions is necessary. The results may well be influenced by the characteristics of Moroccan crossover unions which represent a large part of this specific type of endogamous marriage. One final observation: had the totals of all endogamous unions with the spouse living in the society of origin been included in table 2, the importance of crossover unions, especially among Moroccans, would have increased substantially.

\section{Discussion}

In this paper we have studied the level of endogamy among different immigrant groups in Spain. The data from the National Immigrant Survey (2007) allowed us to include immigrants from a wide variety of origins in Spain and enabled us to look at the determinants of endogamous marriages. Our aim has been to broaden our knowledge on marriage practices and migration. We have also attempted to explain differences and similarities in marriage strategies between men and women of different immigrant origins in Spain. The results of this study confirm a number of the existing expectations with regard to the effects of local marriage markets in terms of size, sex ratio and, the process of integration of immigrants into the host societies. A number of the most relevant results, however, go far beyond these initial expectations.

At the core of this paper we argued that endogamous marriages are the result either of the way the marriage market worked in the host society or of strategies specifically related to migration itself. This premise has received ample confirmation in the results presented here. It has been shown that different indicators related to the marriage market in Spain had an important effect on the likelihood of endogamous marriages of immigrants already present in the country. The observed effects are in line with those of previous studies, suggesting that the same mechanisms related to endogamy are also important in the Spanish case.

The abundant examples of how endogamous marriage patters may also be linked to the process of migration itself, as a part of migration strategies, afford a perspective on endogamy that is much less frequent in the migration literature. Our ability to situate the timing of marriage with respect to the timing of migration allows for this innovative extension. This creates a clear time line that enables us to see how marriage decisions 
are affected by both the run-up to migration and the move itself, as well as by the amount of time spent in the host society. The ultimate conclusion is that marital endogamy is a complex phenomenon; heterogeneous both in its determinants and in its implications.

There are many different varieties of endogamy existing among immigrants in Spain today ${ }^{11}$. Situations in which both spouses marry immediately before or simultaneously with the move to Spain are not infrequent, especially among Argentineans. Another interesting pattern is crossover marriages involving one spouse who is already in Spain and another one in origin. In many (most) of these cases, marriage is followed by the eventual move to Spain of the spouse. These types of marriages are highly prevalent among Moroccans, but are also observable among other groups. Both of these situations are related very clearly to migration strategies themselves. The crossover marriages also involve an added time dimension: the move to Spain is a step by step process with migration taking place sometime after marriage. Considering the relatively high percentages of endogamous unions where the spouse (normally the woman) continues to reside in the country of origin suggests unsurprisingly that the process of family reunification is a vital dimension of migratory strategies.

Very strong country differences can be seen in our results. While some of these differences are related to the chances of meeting a partner once in Spain, most can be attributed to the differential permeability of Spanish society to immigrant groups. This permeability is related to just how long these groups have been in the country, to the depth of traditional ties between both countries, to cultural proximity. They are also clearly related to the willingness of different groups to make adopt a strategy of assimilation, with all of its concomitant implications. On all of these counts, Morocco shows the greatest distance from Spain and has the highest levels of endogamy, and Argentina and Colombia show the lowest.

Migrants from Morocco are by far the most likely to be in an endogamous union. This finding underlines the importance of cultural and religious differences between the sending and host country. These differences continue despite the important historical links and geographical proximity linking both countries. Romanian migrants and, to a lesser extent, Ecuadorian migrants are also more likely to be in an endogamous marriage than Argentineans and Colombians. In the case of Romania, a society with no historical or cultural links to Spain and where immigration to Spain is extremely recent and extremely intense, relatively high levels of endogamy are to be expected. For Ecuadorians, despite the cultural ties to Spain, there are few other historical links to Spain and, besides, among them immigration to Spain is extremely strong and recent. Finally, in the case of Colombians and especially Argentineans, ties with Spain are deep, layered and lasting. This is particularly the case for Argentineans many of whom

\footnotetext{
${ }^{11} \mathrm{Had}$ the variable 'time to marriage' been specified to include persons marrying more than one year prior to migration, a different pattern of endogamy, one entirely unrelated to the migratory experience, would have appeared.
} 
partake in truly transnational families dating back over a century. The extent to which the mechanisms at work in determining endogamous marriages of immigrants vary by ethnic origin is still sketchy.

The effect of the likelihood of meeting potential partners is reflected in our findings for the period of arrival. The lowest levels of endogamy are found among immigrants who arrived in Spain before the onset of the massive migration flows (in 2000). The migrants arriving at those early times were mainly pioneers and the size of the immigrant group was still rather limited at that time, making it much more likely to meet a native Spaniard as a potential partner. It was also a time when Spanish society was much less aware of the existence of immigration (except, perhaps, for that coming from Morocco) and thus the idea of 'them and us', so visible today, did not really exist. In other words, it was a time when the definition of what being Spanish is was really imprecise and basically non-exclusive. All of this appears to change during the period of mass immigration beginning in the year 2000.

In line with previous studies, education has been found to be an important indicator for marriage behavior, with lower educational attainment being clearly linked to endogamous unions. More educated immigrants are evidently more favorably positioned to transcend the natural limits of local ethnic marriage markets. Attitudinal differences - both for immigrants and for Spaniards with respect to immigrants - as well as different work and social networks are likely behind this statistically strong effect. Meeting chances for the more educated take place in less socially constrained contexts. The result we have obtained for people who have studied in Spain (in particular men) who are more likely to be in an ethnic intermarriage is a good example of this mechanism.

When looking at endogamous marriages by gender, important differences have appeared. Evidence has been presented that approximately $30 \%$ of both men and women currently in Spain have no partner at all though the percentage of non-partnered persons at arrival is clearly much higher. When focusing solely on currently married co-resident couples (figure 1) a higher percentage of women were married between one year before arrival and one year after than men (39\% and $25 \%)$. In other words, there is evidence both of women as followers in the migration process and of women who came to Spain on their own. This last point is an indelible characteristic of contemporary international migration flows. If the analysis of migration is based solely on married couples, the incidence of marital endogamy among women is far lower than it is among men (just over half) especially once residence in the host country has been established. Contrary to a part of the existing literature on the subject, these results suggest that Spanish society is more accessible for women than it is for men. It is also possible that the importance of ethnic-oriented marital strategies is lower among women than it is among men. Whatever the reason, it is unquestionable that women have far greater access to both ethnic and native marriage markets than do men, where marital realities are much more limited.

An important but somewhat disturbing result of our study has been the evidence it has provided of how the marriage market and marriage strategies work differently for 
men and for women. When modeling marriage behavior by sex, it became apparent that the set of marriage constraints varied by gender. Most important, for men human capital accumulation was shown to be a very important part of the marriage equation and for women this was less so. Developments in the position of women in education and the labour market in both the sending and receiving societies are crucial denominators for the further development of marriage markets between countries. Additional country level analyses potentially shed light on how and to what extent human capital accumulation is of same relevance for men and women of all origins. This asymmetrical nature of the marriage market may be explained by the fact that both in Spanish society and in the societies of origin, women continue to be measured on a different scale as men. In the future, as societies continue to change both in Spain and in sending countries, these differences on the marriage market can be expected to progressively diminish. The extent to which this actually happens remains to be seen.

Marrying someone of the same ethnic or national origin can be perceived as advantageous for a number of reasons. First, an important advantage to endogamous marriage is that it contributes to the defense of cultural and group identity in a world which is often hostile to that very identity. This is especially the case in host societies where the prevailing attitude towards immigrants ranges from a superior sort of indifference to outright hostility. Second, when immigrants choosing the cultural context in which to raise one's children, maintaining a certain cultural continuity is often perceived as advantageous over a mixed-cultural context in which the second generation may be perceived to be at a disadvantage, at least from the standpoint of identity. Third, migrant networks are often ethnic or origin specific. These networks function both for the protection of the home community and its cultural identity and for the promotion of its members for jobs, contacts, housing, etc. These networks function at different levels (family, local, community, regional or national) and are often transnational in nature. Belonging to one brings with it important advantages and strategies that are coherent and often very effective (Massey et al. 1998; Portes and Jensen 1989; Portes 1998; Portes and Börocz 1998). Finally, marrying-in can also be understood as a well-defined strategy designed to facilitate migration itself. Migrating as a newly married young couple is one example of this, because here the risks of migration are shared. Cross marriages, with one spouse in the host country and the other at home, is another specific example of this type of strategy. In this case, however, not only are risks reduced but having one spouse in the host country -often with papers- offers important practical advantages for the spouse left at home. Here, whenever possible, it is useful to be able to distinguish between spouses where one partner migrates first and then brings the other as opposed to those in which the marriage actually takes place after one spouse's migratory move and before the other's.

Our data only provide information on the country of birth of the informant. The second generation, those born in Spain with foreign born parents, cannot be distinguished as such. This may result in an overestimation of endogamous marriages as all those with migrant parentage are included with the Spanish born. Given the recent nature of immi- 
gration to Spain this issue might not be too much of a problem in the current context. For the near future it is, however, relevant to see how and to what extent marriage strategies of the second generation are going to differ from those who migrated themselves.

\section{ReFERENCES}

Alba, R. D. and G. Reig 1986. "Patterns of ethnic marriage in the United States." Social Forces 65 : 202-203.

Arango, J. 2004. "La inmigración en España a comienzos del siglo XXl”. Pp. 161-186 in Leal, J. (ed.) Informe sobre la situación demográfica en España. Madrid: Fundación Fernando Abril Martorell.

Blau, P. M., and J. E. Schwartz. 1984. Crosscutting Social Circles: Testing a Macrostructural Theory of Intergroup Relations. New York: Academic Press.

Castles, S. and M. Miller. 2004. La era de la migración: movimientos internacionales de población en el mundo moderno. México: Universidad Autónoma de Zacatecas.

Castro, T. 2002. "Consensual Unions in Latin America: Persistence of a Dual Nuptiality System." Journal of Comparative Family Studies 33 (1): 35-55.

Carling, J. 2005. The Gender Dimensions of International Migration. GCIM, paper nº 35. Geneva.

Coleman, D. 2008. "Trends in Fertility and Intermarriage among Immigrant Populations in Western Europe as Measures of Integration." Pp. 321-359 in Kim, D.S. (ed.) Cross-border marriage, Process and Dynamics. Seoul: Institute of Population and Aging Research, Hanyang University.

Cortina, C., A. Esteve and A. Domingo. 2008. "Marriage patterns of the foreign-born population in a new country of immigration: The case of Spain." International Migration Review 42 (4): 877- 902.

De Valk, H., A. C. Liefbroer, I. Esveldt, and K. Henkens. 2004. "Family formation and cultural integration among migrants in the Netherlands." Genus 55: 9-36.

Donato, K. M., D. Gabbaccia, J. Holdaway, M. Manalansan and P. R. Pessar. 2006. "A Glass Half Full? Gender in Migration Studies." International Migration Review 40 (1): 3-26.

Esteve, A., A. del Rey, and C. Cortina. 2009. International Migration and Union Formation: an exploration of pathway interactions. Poster presented at the 2009 annual PAA conference, Detroit, US, April 30 - May 2009.

González-Ferrer, A. 2006. "Who Do Immigrants Marry? Partner Choice Among Single Immigrants in Germany." European Sociological Review 22 (2): 171-185.

Gordon, M. M. 1964. Assimilation in American life. New York: Oxford University Press.

Hooghiemstra, E. 2003. Trouwen over de grens: Achtergronden van partnerkeuze van Turken en Marokkanen in Nederland. Den Haag: Sociaal en Cultureel Planbureau. 
Kalmijn, M. 1993. "Trends in Black/ White intermarriage." Social Forces 72: 119-146.

Kalmijn, M. 1998. "Intermarriage and homogamy: Causes, patterns, trends." Annual Review of Sociology 24: 395-421.

Kalmijn, M. and F. Van Tubergen. 2006. "Ethnic intermarriage in the Netherlands: Confirmations and refutations of accepted insights." European Journal of Population 22: 371-397.

Khoo, S.E. 2004. "Intermarriage in Australia. Patterns by ancestry, gender and generation." People and Place 12 (2): 34-44.

Lee, S.M. and M. Fernandez. 1998. "Trends in Asian American Racial/Ethnic Intermarriage: A Comparison of 1980 and 1990 Census Data." Sociological Perspectives 41 (2): 323-342.

Lieberson, S., and M. Waters. 1988. From many strands: Ethnic and racial groups in contemporary America. New York: Russell Sage Foundation.

Massey, D. S., J. Arango, G. Hugo, A. Kouaouci, A. Pellegrino and J. E. Taylor. 1998. Worlds in Motion; Understanding International Migration at the End of the Millenium. Oxford: Clarendon Press.

McCaa, R. 1993. "Ethnic intermarriage and gender in New York City." Journal of Interdisciplinary History 24(2): 207-231.

Merton, R. K. 1941. "Intermarriage and the Social Structure: Fact and Theory." Psychiatry 4: 361-374.

Moya, J. C. 1997. Cousins and Strangers: Spanish immigrants in Buenos Aires, 1850-1930. Berkeley: University of California Press.

Oppenheimer, V. K. 1988. "A Theory of Marriage Timing." The American Journal of Sociology, 94(3): 563-591.

Qian, Z. 1997. "Breaking the racial barriers. Variation in interracial marriage between 1980 and 1990." Demography 34 (2): 263-276.

Qian, Z., and D.T. Lichter. 2001. "Measuring marital assimilation: Intermarriage among natives and immigrants." Social Science Research 30: 289-312.

Pagnini, D., and S. Morgan. 1990. "Intermarriage and Social Distance Among U.S, Immigrants at the turn of the Century." American Journal of Sociology 96 (3): 405-432.

Pedone, C. and S. Gil. 2008. "Maternidades transnacionales entre América Latina y el Estado español. El impacto de las políticas migratorias en las estrategias de reagrupación familiar". Pp. 149-176 in C. Solé, S. P. and L. Cavalcanti, (ed.) Nuevos retos del transnacionalismo en el estudio de las migraciones, Madrid, OPI-Ministerio de Trabajo e Inmigración.

Portes, A. and Jensen, L. 1989. "The Enclave and the Entrants: Patterns of Ethnic Enterprise in Miami Before and After Mariel”. American Sociological Review, 54: 929-949.

Portes, A. and M. Zhou. 1993. "Segmented Assimilation and Its Variants." Annals of the American Academy of Political and Social Science 530: 74-96. 
Portes, A. 1998. "Social Capital: Its Origins and Applications in Modern Sociology." Annual Review of Sociology 24: 1-24.

Portes, A. and J. Börocz. 1998. "Migración contemporánea. Perspectivas teóricas sobre sus determinantes y sus modalidades de incorporación." Pp. 43-73 in Malgesini, G. (ed.) Cruzando las fronteras. Migraciones en el Sistema Mundial, Barcelona, ICARIA.

Portes, A. and R. G. Rumbaut (eds.) 2001. Legacies: The story if the immigrant second generation. Berkeley, CA: University of California Press.

Portes, A. 2008. Immigrations and social chance: conceptual reflexion. Conferences on Population and Society. Conference. Madrid: Ramon Areces Fundation/ GEPS.

Reher, D. S. 2004. "Migrant communities and migrant networks in urban areas in the past." Pp. 67-96 in Sonnino, E. (ed.) Living in the City, Roma: Università degli Studi di Roma La Sapienze.

Reher, D., L. Cortés, F. González, M. Requena, M. Sánchez, A. Sanz, and M. Stanek. 2008. Informe Encuesta Nacional de Inmigrantes (ENI-2007). Madrid: Instituto Nacional de Estadística.

Reher, D. and M. Requena. 2009. "The National Immigrant Survey of Spain. A new data source for migration studies in Europe." Demographic Research 20 (12): 253-278.

Requena, M. and D. Reher. 2009. "El impacto de la inmigración en la sociedad española." Chp. 1 in D. Reher, and M. Requena (eds) Las múltiples caras de la inmigración en España. Madrid: Alianza Editorial (in press, expected publication: September 2009).

Rodriguez, D. 2006. "Mixed marriages and transnational families in the intercultural context: A case study of African-Spanish couples in Catalonia." Journal of ethnic and Migration Studies 32 (3): 403-433.

Roig, M. and T. Castro. 2007. "Childbearing Patterns of Foreign Women in a New Immigration Country: The Case of Spain." Population English edition 62 (3): 351-380 Population Édition française 62 (3): 419-446.

Sánchez Alonso, B. 2001. "Visiones de la emigración en el siglo XX: De emigrantes a inmigrantes." Pp. 101-118 in Morales, A. (ed.) Las claves de la España del siglo XX. La modernización social. Madrid: Sociedad Estatal Nuevo Milenio.

Van Tubergen, F. and I. Maas. 2007. "Ethnic intermarriage among immigrants in the Netherlands: an analysis of population data." Social Science Research 36: 1065-1086.

MARÍA SÁNCHEZ-DOMÍNGUEZ received her PhD in Sociology from the Universidad Complutense de Madrid in December, 2010 and currently participates as a postdoctoral researcher on the project: "The National Immigrant Survey (ENI): national and international comparative perspectives" (CSO200803616). Her research interests center on international migration, union and family formation among immigrants, social integration and family. 
HELGA DE VALK is Professor at Interface Demography, Free University Brussels and senior researcher at the Netherlands Interdisciplinary Demographic Institute (NIDI) in The Hague. Her research focuses on the transition to adulthood of immigrant youth, educational inequality, union and family formation, the second generation and intergenerational relationships in immigrant families. Currently she works, among others, on her ERC starting grant project "Families of migrant origin: a life course perspective".

DAVID REHER is Professor (Catedrático) of Sociology at the Universidad Complutense de Madrid. He is a founding member of the Asociación de Demografía Histórica (ADEH), Vice-President and President of the ADEH, Chair of the Historical Demography Committee of the International Union for the Scientific Study of Population (IUSSP), Director of the Grupo de Estudios Población y Sociedad (GEPS) and Principal Investigator of the research team that originally proposed the National Immigrant Survey and carried it out in collaboration with the Spanish Statistical Office (Instituto Nacional de Estadística - INE). He is author of numerous books, book chapters and scientific articles in the fields of demography, population history and the history of the family.

RECIBIDO: 20/12/2010

ACEPTADO: $31 / 01 / 2011$ 